\title{
A Promising Way to Dispose of Fatty Waste by Hydrolysis and Study of the Conditions for Immobilization of Rhizopus Japonicus Lipase on Carriers
}

\author{
Viktoriia Skliar ${ }^{1 *}$, Galina Krusir ${ }^{1}$, Hanna Shunko ${ }^{1}$, Valentyna Zakharchuk², \\ Myroslav Malovanyy ${ }^{3}$ \\ 1 Odessa National Academy of Food Technologies, Ukraine \\ 2 Odessa National Economic University, Ukraine \\ 3 Lviv Polytechnic National University, Ukraine \\ * Corresponding author's e-mail: vsklyar1993@gmail.com
}

\begin{abstract}
The hydrogenation process in oil and fat production is accompanied by the formation of a large amount of waste, the majority of which includes spent catalysts and spent sorbents. The bioconversion of lipids through the use of immobilized enzyme preparations expands the possibilities and is one of the most powerful resource potentials of environmental biotechnology. The adsorption methods are most effective, which is due to the ease of the binding process, the low cost of the carrier and the absence of toxic substances. Immobilization of adsorption provides a large surface area, which is important for the lipolytic enzymes performing catalysis at the interface. In most cases, adsorption slightly reduces the activity of lipases and, which is extremely important, does not affect their specificity. It was shown that the use of activated carbon with a grain size of 2.0-2.8 as a carrier for immobilization of lipase, leads to maximum preservation of the initial lipolytic activity. The weight ratio of carrier/ enzyme, optimal in terms of preservation of lipolytic activity, was $1 \mathrm{~g}$ of biopolymer carrier per $500 \mathrm{mg}$ of lipase (1: 0.5) with preservation of $36.33 \%$ of the initial activity of the native enzyme. From the obtained experimental data, it follows that the rational conditions for the immobilization of Rhizopus japonicus is GM 1.5 , temperature $25^{\circ} \mathrm{C}$, duration of immobilization 15 minutes, the size of particles of activated carbon as a matrix is $2.0-2.8 \mathrm{~mm}$. The lipolytic activity of the enzyme immobilized under these conditions is preserved by more than $30 \%$ compared with the native one, which is a high indicator of the preservation of activity.
\end{abstract}

Keywords: lipase, enzyme, immobilization technology, waste, waste sorbent, straw, ecological biotechnology, hydrogenation of vegetable oils

\section{INTRODUCTION}

The oil and fat industry of Ukraine today has a dynamic of sustainable development and remains an integral part of the global market for oilseeds and their processed products. The total world market for sunflower oil is 10 million tons, and Ukraine occupies $60 \%$ of this market. The oil and fat plants are used to obtain vegetable oils, hydrogenated oil, margarine, mayonnaise, glycerin, soap and fat-based detergents, drying oils and other products, the production of which uses vegetable oils as raw materials. At different stages of the processing of plant materials, the waste and by-products that contain a significant amount of fatty acids and related substances as well as constitute a valuable raw material for many industries are generated.

The technology for cleaning vegetable oils and salomas (hydrogenated oils) includes such steps as bleaching and filtering. When bleaching, special bleaching powders are used, which have the ability to absorb dyes and keep them on their surface. With further filtering, the whitening powders, together with the absorbed dyes, are separated from oils and hydrogenated oil. The amount 
of sorbent depends on the content of dyes in the oil and the desired degree of illumination. Depending on the technology, 12-15 kg of bleaching clay is used per 1 ton of vegetable oil. Depending on the technological process, the oil content in bleaching clays after their use can reach $50 \%$. The process of vegetable oils hydrogenation in oil production is accompanied by the formation of large-scale waste, the majority of which are spent catalyst and spent clay (sorbent) (Krussir et al. 2014., Arutyunyan et al. 2004).

The hazardous properties of the waste are that the clay is able to ignite spontaneously upon contact with air. Waste classifier DK 005-96, approved by Gosstandart Order No. 89 of 02.29.1996 does not contain waste classification by hazard class. Since there is no single legislative document regarding the hazard of waste in the country today and the approval of the hazard class is carried out by the regional state environmental administrations (and the sanitary-epidemiological service), some territorial discrepancies arise. According to the Register of Waste Generation, Treatment and Disposal Objects provided by the Vinnytsia Regional State Administration, waste clay is a hazard class IV waste. Total waste generation (hazard classes) is 113,460 tonnes/year.

Ukraine ratified the "Association Agreement with the European Union, September 16, 2014). Directives of the European Parliament and of the Council of the European Communities "On Waste" (75/442/EU of 07.15.1975, 2008/98/EC of 11.19.2008) and, with subsequent amendments to the directives of the Council of the EU, established fundamental provisions in the field of activity on waste,. The key concepts determining the further ways of waste management at enterprises and facilities that are sources of their formation and carry out activities with waste were defined (On Ratification of the Association Agreement between the European Union, the European Atomic Energy Community and their member states and Ukraine, 2014, Council Directive 1975, Directive 2008).

The ways to dispose of the bleaching clay suggest its use in the manufacture of bricks, expanded clay, cement, drying oil, aerated concrete, soap pastes. The use of bleaching clay is also possible as an additive in road bitumen, as well as in animal feed. The main method of its disposal from the process of vegetable oils hydrogenation is a landfill of solid household waste. Among the methods for processing fatty raw materials, recycling is a promising option, enabling to obtain of a number of technical products. The technology of the process is based on the biotechnological method.

It is known that enzymes, as a class of biological molecules, have very low stability. Even small deviations of external conditions from those that are characteristic of the microenvironment of enzymes in the cell may be sufficient to disrupt the structure and function of the enzymes, that is, to inactivate them. In this regard, the actual problem is to increase the stability and efficiency of lipase by immobilizing the enzyme preparations, which increases the number of enzyme molecules per unit area, improving the efficiency of enzymatic hydrolysis.

The simplest way to solve the problem of spent bleaching clays disposal in the technology for refining vegetable oils is a technology that involves their removal to landfills of solid waste.

Waste clay can be used as mineral additives in animal feed, but their use in this direction is impractical, since the economic costs significantly exceed the positive effect of fattening. There are methods for degreasing the spent clays using supercritical carbon dioxide or light solvents, as well as under pressure in combination with water and sodium hydroxide. The use of bleaching clay as an alternative source of raw materials for the production of biodiesel and a number of technologies based on the degreasing of waste is proposed. A lot of bleaching clay or filter powder can be used as raw materials in the production of asphalt, concrete, brick and other building materials (The official website of Vinnitsa Regional State Administration). There is a method for the disposal of the oil-containing wastes by making household pastes for cleaning, detergents. Some authors have proposed a production line of the biological products based on the technogenic wastes of the oil and fat industry, the technology of controlled burning using the heat received for technological needs. The studies on the process of vegetable oil bleaching and the properties of whitening clays show that the problem of recycling waste oil bleaching is currently solved. However, the issue of recyclingand recycling the waste from the process of rewhitening (demetallizing) the straw has not been solved yet. Therefore, these identified unresolved issues allowed us to identify the directions in the processing and use of waste clay waste demetalization (Romanovskaya and Romanovsky 2009, O’Brien 2007). 
The most resource-efficient, energy-efficient and environmentally friendly method is the biotechnological recycling of spent clay (sorbent) by enzymatic hydrolysis.

The results of studies in which the efficiency of using the Rhizopus japonicus lipase in the hydrolysis of hydrogenated fat (Sklyar et al. 2019) were shown; the physical and chemical properties of lipase (Skliar et al. 2019) were studied and it is found that the lipase is very unstable. The reason may include even small deviations of the external conditions from those that are characteristic of the microenvironment of enzymes in the cell. One solution to this problem is the immobilization of lipase. This suggests that it is advisable to conduct the research on this topic.

Compared with the native ones, the immobilized preparations of enzymes are characterized by a number of advantages, such as $\mathrm{pH}$ expansion and thermo-optimal action, increase in $\mathrm{pH}$ and thermal stability, prolongation of the action of immobilized enzymes, the matrix during the operation of immobilized preparations under real conditions protects the enzyme from the aggressive effects of the reaction medium. The disadvantage of the immobilization method is a significant decrease in the enzymatic activity, but the listed advantages can compensate for this disadvantage (Cherno et al. 2009a).

The most effective method for the stabilization of enzymes is their immobilization on carriers of different nature. Hydrophobic carriers, anion exchange, cation exchange and chelate resins are used as matrices for immobilization of lipases. In addition, a method for preparing immobilized lipase particles was proposed, which includes the steps of preparing an emulsion, where the aqueous phase dissolves lipase, and the substance functions as a lipase carrier, is dispersed in the hydrophobic phase, followed by removing water from the emulsion to convert its aqueous phase into solid particles, covered with lipase (Cherno et al. 2010a, Pieskova and Dekhtiarenko 2014).

The methods for immobilizing lipases include adsorption on insoluble carriers; transition of the gel into the pores; spatial separation of the enzyme from the remaining volume of the reaction mixture using a semipermeable partition (membrane) inclusion in a two-phase reaction medium, where the enzyme is soluble and can be contained only in one of the phases, etc. (Cherno et al. 2009b).

The analysis of the literature data shows that the adsorption methods are most effective. This is due to the ease of the binding process, the low cost of the carrier and the absence of toxic substances (Krussir 2010, Cherno 2010b). Immobilization of adsorption provides a large surface area, which is important for the lipolytic enzymes performing catalysis at the interface. In most cases, adsorption slightly reduces the activity of lipases and, which is extremely important, does not affect their specificity. For immobilization of lipolytic enzymes using adsorption, various carriers are used: kieselguhr, porous nylon and latex, hydrophobic zeolite, synthetic resins, polypropylene, aluminum oxide, Amberlite, etc. (Paiva et al. 2000, Ramos et al. 2015). Lipase for the treatment of animal waste and wastewater is immobilized in polyelectrolyte (Gunasekaran and Das 2005, Nekrasov et al. 2011, Kovaleva et al. 2008). One of the priorities of biotechnology is the immobilization of enzymes on the surface of yeast cells (Samoilova et al. 2013). The chemical methods of enzyme immobilization today are the dominant technique of obtaining heterogeneous biocatalysts.

The most effective lipase immobilization matrices are activated carbon, clays and biopolymer matrices. Various inorganic clays, namely, kieselgur, Askanite, bergmeal, activated carbon are widely used to obtain the immobilized forms of enzymes and other biologically active substances that are used in industry. This is due to their characteristics such as high adsorption properties, developed surface in combination with sufficient permeability for substrates, as well as the presence of various functional groups.

As matrices for the immobilization of the enzyme, the food clays of inorganic origin and other- polymeric matrices which are most widely used as carriers of enzymes, were chosen and are used in the oil and fat industry. The presence of various functional groups in them, the developed surface determines their high sorption capacity relative to inorganic and other polar molecules.

In previous works (Skliar et al. 2019, Sklyar 2019), the efficiency of using lipase of Rhizopus japonicus in the hydrolysis of hydrogenated fat was shown and the conditions for productive hydrolysis of waste were determined. The weight ratio of lipase: substrate is 1:50, the temperature of the medium is $40^{\circ} \mathrm{C}$, the $\mathrm{pH}$ of the reaction mixture is 7.0. The previously presented experimental data indicate a low $\mathrm{pH}$ and thermal stability of the enzyme, indicating the need for its stabilization. 
The purpose of the work was the selection of the immobilization conditions for the disposal of the fat fraction of waste based on the lipase of microbial origin of Rhizopus japonicus.

The task of the work was to determine the optimal weight ratio of carrier: enzyme; to investigate the dependence of the activity of immobilized lipase on the hydromodule, on temperature, on the duration of immobilization as well as the dependence of the lipolytic activity of immobilized lipase on the particle size.

\section{MATERIALS AND METHODS}

The objects of the study were:

- Hydrogenation waste of vegetable oils and fats, namely that of the bleaching process. In order to eliminate the influence on the lipase of the mineral substances contained in the waste, $40 \%$ of the brine emulsion was used as a substrate, which is the main component of the waste of its production.

- Rhizopus japonicus lipase produced by Enzim enterprise (Ladyzhyn, Vinnytsia region, Ukraine) was considered as a part of waste, which shows the highest activity in relation to hydrogenated fat, substantiates its use for hydrogenated fat hydrolysis.

- In order to study the processes of lipase adsorption of Rhizopus japonicus, the following carriers were used - diatomaceous earth (Trepel Group LLC, Kirovograd Mechanical Plant CJSC), Askanite (Askangel Alliance Georgia LLC), activated carbon (The first gas company LLC), bergmeal (Trepel LLC Group, CJSC Kirovograd Mechanical Plant), agar (LLC Chemical Supply), carrageenan (LLC Chemical Supply), chitosan (Xi'an Sonwu Biotech Co., Ltd.).

The lipolytic activity was determined with the Ota and Yamada titrimetric method (Polygalina G.V., 2003), which is based on the calculation of the amount of fatty acids formed during the hydrolysis of the substrate. A $40 \%$ hydrogenated fat emulsion stabilized with polyvinyl alcohol was used as a substrate. The amount of enzyme that releases $1 \mu \mathrm{mol}$ of acid from $40 \%$ hydrogenated fat suspension at $37^{\circ} \mathrm{C}$ in 1 hour was taken as a unit of activity. To a tube containing $8-15 \mathrm{mg}$ of sample, $1 \mathrm{~cm}^{3}$ of water was added. Than $1 \%$ lipase solution, and $0.8 \mathrm{~cm}^{3}$ of phosphate buffer (the $\mathrm{pH}$ of the medium corresponded to the $\mathrm{pH}$ optimum of lipase), and thermostatically held at $37^{\circ} \mathrm{C}$ for $5 \mathrm{~min}$. Then, $1.0 \mathrm{~cm}^{3}$ of thermostated $40 \%$ suspension of hydrogenated fat with polyvinyl alcohol, was added under the same conditions. Exactly after $1 \mathrm{~h}$ of incubation, the reaction was interrupted by the addition of $5 \mathrm{~cm}^{3}$ of $96 \%$ ethanol. In the control sample, the hydrogenated fat emulsion was added after ethanol. Three drops of phenolphthalein solution were added to the control and experimental samples and titrated with $0.05 \mathrm{n}$ sodium hydroxide solution to a light pink color. The level of the lipase activity was evaluated in arbitrary units from the difference in the amount of alkali, followed by titration of the experimental and control samples during the hydrolysis of $40 \%$ hydrogenated fat emulsion.

The activity of lipase was calculated according to the formula:

$$
\mathrm{LA}=\frac{\left(\mathrm{A}-\mathrm{A}_{1}\right)}{\mathrm{B}} * 100, \mathrm{LU} / \mathrm{g}
$$

where $A-$ is the amount of $0.05 \mathrm{M} \mathrm{NAOH}$ that went for the titration of the prototype, $\mathrm{cm}^{3}$;

$A 1$ - is the amount of $0.05 \mathrm{M} \mathrm{NAOH}$ that went for the titration of the control sample, $\mathrm{cm}^{3}$;

$B$ - the amount of enzyme in the reaction mixture, $\mathrm{mg}$;

100 - coefficient for conversion into a micromolar;

$L A-$ lipolytic activity.

$L U$ - lipollytic unit.

Immobilization of the enzyme with the method of physical adsorption (physical sorption) was carried out as follows: a shot of the carrier $(1 \mathrm{~g})$ was impregnated with $10 \%$ enzyme solution in 0, $1 \mathrm{M}$ phosphate buffer, $\mathrm{pH} 7.0$ units, then dried and again impregnated with enzyme solution until the desired weight ratio carrier: enzyme was reached (Kates 1975).

\section{RESULTS AND DISCUSSION}

In order to provide the characteristics of the enzyme used as a substrate, hydrogenated fat was taken, which is the main component of the waste from its production. This process is shown in Figure 1. Figure 2 presents the waste treatment scheme. 




Fig. 1. Technological scheme of the production of hydrogenated fat

One of the traditional methods for stabilizing enzymes is their adsorption on biopolymer matrices. In order to obtain a stable lipase preparation, which exhibits the lipolytic activity sufficient for enzyme digestion of hydrogenated fat, immobilization of Rhizopus japonicus lipase on the carriers of inorganic origin was carried out.

During the studies, the optimal conditions for sorption immobilization were selected: the carrier was impregnated with $10 \%$ enzyme solution in $0.1 \mathrm{M}$ phosphate buffer solution, $\mathrm{pH} 7.0$ units. $\mathrm{pH}$

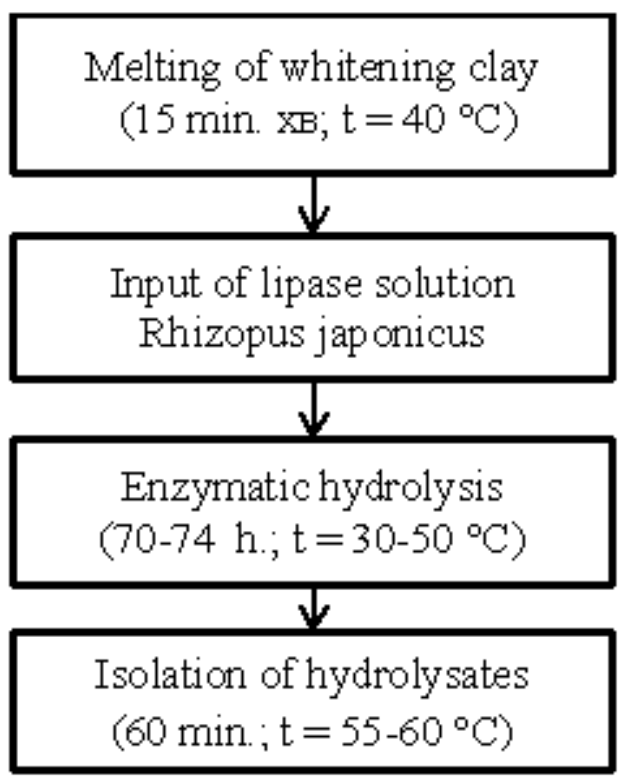

Fig. 2. Schematic diagram of waste treatment at $23^{\circ} \mathrm{C}$, using $\mathrm{GM} 3$ for agar-agar and carrageenan, GM 1 for various clays (kieselgur, Askanite, bergmeal) and GM 1.5 for activated charcoal and chitosan, the preparation dried at $40^{\circ} \mathrm{C}$.

The choice of carrier for immobilization of lipase was carried out to maximize the preservation of the original lipolytic activity. The experimental results of determining the optimal weight ratio of carrier: enzyme are given in Table. 1.

Thus, the use of activated carbon with a grain size of $2.0-2.8$ as a carrier for immobilizing of lipase, leads to the maximum preservation of the original lipolytic activity. The weight ratio of carrier: enzyme, optimal in terms of preservation of lipolytic activity, was $1 \mathrm{~g}$ of biopolymer carrier per $500 \mathrm{mg}$ of lipase (1:0.5) with preservation of $36.33 \%$ of the initial activity of the native enzyme.

The following factors influence the immobilization efficiency: temperature, hydromodule (HM, solid phase-liquid weight ratio), duration of immobilization process.

The experimental data on the effect of hydromodule, temperature and duration of the immobilization process on the enzymatic activity immobilized on activated carbon with a weight ratio of carrier inhibitor (1: 0.5) are shown in Figures 3-5.

As evidenced by the results of the study on the effect of hydromodule immobilization on the conservation of enzymatic activity, which are shown in Fig. 3, the greatest value of preservation of lipolytic activity is observed with GM 1.5. 
Table 1. Determination of optimal weight ratios carrier: enzyme

\begin{tabular}{|c|c|c|c|}
\hline \multirow[b]{2}{*}{ Carrier } & \multirow{2}{*}{$\begin{array}{c}\text { Weight ratio } \\
\text { carrier/ } \\
\text { enzyme }\end{array}$} & \multicolumn{2}{|c|}{ Lipolytic activity } \\
\hline & & LU/g carrier & $\begin{array}{l}\% \text { of the } \\
\text { preserv, of } \\
\text { the native }\end{array}$ \\
\hline $\begin{array}{l}\text { Kieselguhr } \\
\text { (Ukraine ) }\end{array}$ & $\begin{array}{l}1: 0.1 \\
1: 0.3 \\
1: 0.5 \\
1: 0.7 \\
1: 0.9\end{array}$ & $\begin{array}{l}10.0 \\
26.1 \\
69.3 \\
91.4 \\
55.2\end{array}$ & $\begin{array}{l}23.81 \\
20.71 \\
33.00 \\
31.09 \\
14.60\end{array}$ \\
\hline $\begin{array}{l}\text { Activated } \\
\text { carbon } \\
(2.0-2.8) \\
\text { (Ukraine) }\end{array}$ & $\begin{array}{l}1: 0.1 \\
1: 0.3 \\
1: 0.5 \\
1: 0.7 \\
1: 0.9\end{array}$ & $\begin{array}{l}14.0 \\
34.1 \\
76.3 \\
99.4 \\
88.2\end{array}$ & $\begin{array}{l}33.33 \\
27.06 \\
36.33 \\
33.81 \\
23.33\end{array}$ \\
\hline $\begin{array}{l}\text { Askanite } \\
\text { (Georgia) }\end{array}$ & $\begin{array}{l}1: 0.1 \\
1: 0.3 \\
1: 0.5 \\
1: 0.7 \\
1: 0.9\end{array}$ & $\begin{array}{c}7.0 \\
28.1 \\
66.4 \\
52.3 \\
50.1\end{array}$ & $\begin{array}{l}16.67 \\
22.30 \\
31.62 \\
17.79 \\
13.25\end{array}$ \\
\hline $\begin{array}{l}\text { Bergmeal } \\
\text { (diatomite) } \\
\text { (Ukraine) }\end{array}$ & $\begin{array}{l}1: 0.1 \\
1: 0.3 \\
1: 0.5 \\
1: 0.7 \\
1: 0.9\end{array}$ & $\begin{array}{c}6.2 \\
13.1 \\
62.3 \\
66.4 \\
52.1\end{array}$ & $\begin{array}{l}14.76 \\
10.40 \\
29.67 \\
22.59 \\
13.78 \\
\end{array}$ \\
\hline Agar (China) & $\begin{array}{l}1: 0.1 \\
1: 0.3 \\
1: 0.5 \\
1: 0.7 \\
1: 0.9\end{array}$ & $\begin{array}{c}8.6 \\
26.2 \\
58.1 \\
62.3 \\
47.4\end{array}$ & $\begin{array}{l}20.48 \\
20.79 \\
27.67 \\
21.19 \\
12.54\end{array}$ \\
\hline $\begin{array}{l}\text { Carrageenan } \\
\text { (E407) } \\
\text { (China) }\end{array}$ & $\begin{array}{l}1: 0.1 \\
1: 0.3 \\
1: 0.5 \\
1: 0.7 \\
1: 0.9\end{array}$ & $\begin{array}{c}8.1 \\
19.3 \\
54.2 \\
62.1 \\
47.4\end{array}$ & $\begin{array}{l}19.29 \\
15.32 \\
25.81 \\
21.12 \\
12.54\end{array}$ \\
\hline $\begin{array}{l}\text { Chitosan } \\
\text { (China) }\end{array}$ & $\begin{array}{l}1: 0.1 \\
1: 0.3 \\
1: 0.5 \\
1: 0.7 \\
1: 0.9\end{array}$ & $\begin{array}{c}6.2 \\
23.5 \\
69.4 \\
87.1 \\
77.3\end{array}$ & $\begin{array}{l}14.76 \\
18.65 \\
33.05 \\
29.63 \\
20.45\end{array}$ \\
\hline
\end{tabular}

The results of the study of the effect of temperature on the efficiency of the process of immobilizing of lipase on activated carbon, which are shown in Fig. 4, show that immobilized lipase is stable in the range of $15=35^{\circ} \mathrm{C}$, and the greatest activity is observed at $25^{\circ} \mathrm{C}$. As the temperature rises, the activity sharply decreases.

The results of the experimental studies shown in Fig. 5 indicate that the maximum preservation of lipolytic activity is observed after 15 minutes of the immobilization process. Further preservation of activity is probably due to the intensification of denaturation processes.

From the results of experimental studies, it can be concluded that the rational conditions for the immobilization of Rhizopus japonicus lipase is GM 1.5 , the temperature is $25^{\circ} \mathrm{C}$, the duration of immobilization is 15 minutes.

Due to the fact that the physicomechanical properties of the carrier significantly affect the immobilization, the dependence of the lipolytic activity of the immobilized form of lipase on the size of the matrix particles was investigated. The weight ratio of the enzyme carrier is $1: 0.5$. The research results are summarized in table 2 .

The results of the experimental data given in table 2, enable to state that the maximum inhibitory activity is observed when using activated carbon with a particle size of 2.0-2.8.

\section{CONCLUSIONS}

From the studies it follows that the lipase immobilization improved the conditions for processing (fermentolysis) of the waste hydrogenation of vegetable oils in oil and fat production. Therefore, from the above-mentioned results it can be seen that the use of activated carbon with a grain size of $2.0-2.8 \mathrm{~mm}$ as a carrier for immobilizing of lipase leads to the maximum preservation of the initial lipolytic activity; when the



Fig. 3. The dependence of the activity of immobilized lipase on hydromodule 


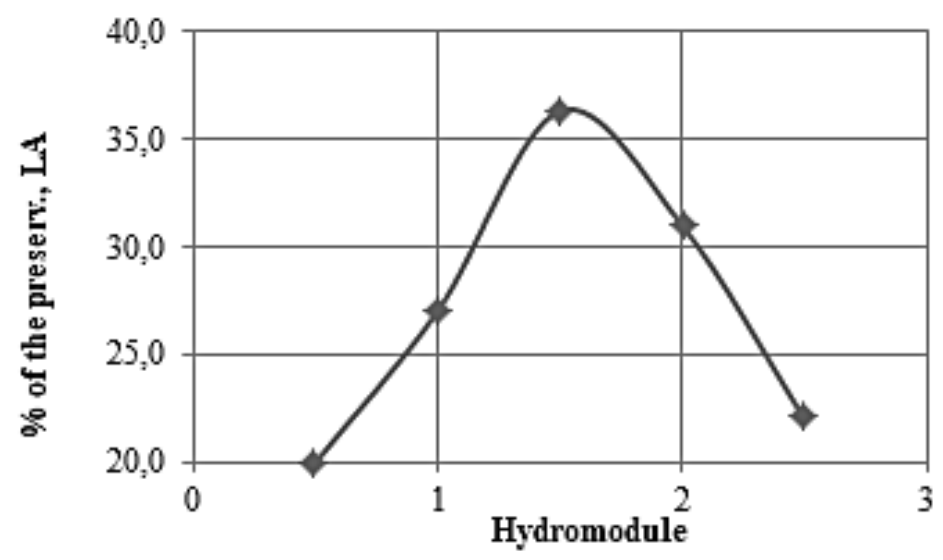

Fig. 4. The dependence of the activity of immobilized lipase on temperature

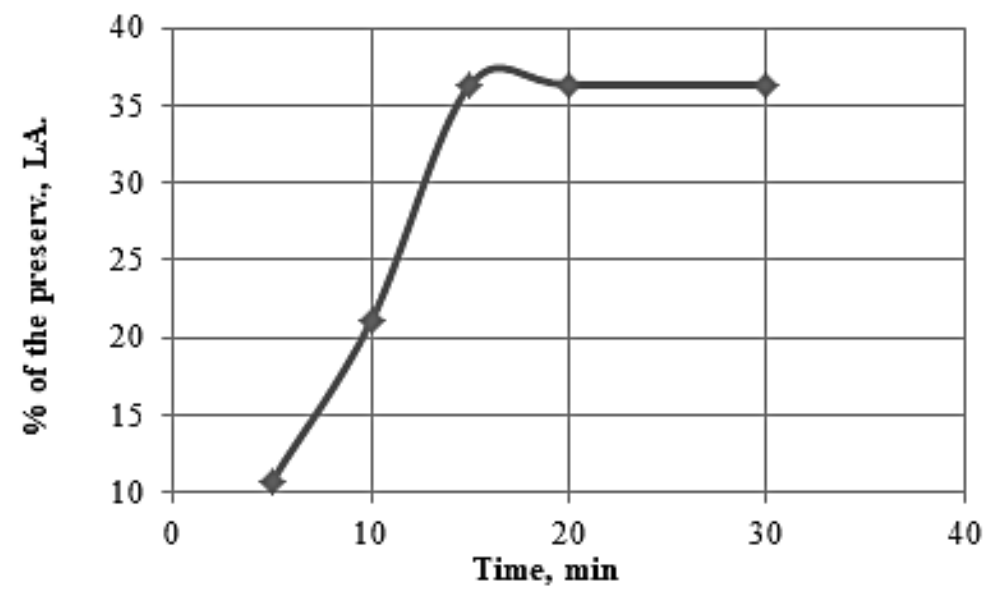

Fig. 5. The dependence of the activity of immobilized lipase on the duration of immobilization

carrier: enzyme $=1: 0.5$ weight ratio, it amounts to $36.33 \%$ of the initial lipolytic activity.

From the obtained experimental data, it follows that the rational conditions for the immobilization of Rhizopus japonicus is GM 1.5, temperature $25^{\circ} \mathrm{C}$, duration of immobilization $15 \mathrm{~min}$, the size of the matrix particles $-2.0-2.8 \mathrm{~mm}$. The lipolytic activity of the enzyme immobilized under these conditions is preserved by more than $30 \%$ compared with the native one, which is a high indicator of the preservation of activity.

Table 2. Investigation of lipolytic activity of immobilized lipase from particle size

\begin{tabular}{|c|c|c|}
\hline No. & $\begin{array}{c}\text { Size of activated carbon particles, } \\
\mathrm{mm}\end{array}$ & $\begin{array}{c}\text { \% of the preserv, } \\
\text { LA }\end{array}$ \\
\hline 1 & $0.5-1.8$ & 28.2 \\
\hline 2 & $1.0-2.5$ & 31.4 \\
\hline 3 & $2.0-2.8$ & 36.3 \\
\hline 4 & $2.8-5.0$ & 27.8 \\
\hline 5 & $3.0-6.0$ & 24.2 \\
\hline
\end{tabular}

\section{REFERENCES}

1. Arutyunyan N.S., Kornena E.P., Nesterova E.A. 2004. Refining of oils and fats: Theoretical foundations, practice, technology, equipment. GIORD. $\mathrm{SPb}$. (in Russian)

2. EU-Ukraine Association Agreement. (2014). Association Agreement between the European Union and the European Atomic Energy Community and their member states, of the one part. Official Journal of the European Union. [Electronic resource]. Retrieved from http://trade.ec.europa.eu/doclib/docs/2016/ november/tradoc_155103.pdf. (in English)

3. Cherno N.K., Krusir G.V., Rusieva Ya.P. 2010a. Complex formation as a method of immobilization of soy inhibitors. Food science and technology, 1, 24-27. (in Ukrainian)

4. Cherno N.K., Krussir G.V., Kovalenko O.V. 2009a. Biocorrectors of etching processes Monograph. Astroprint, Odessa (in Ukrainian)

5. Cherno N.K., Krussir G.V., Sevast'yanova O.V., Yashkyna V.V. 2010b. Biotechnology of BAD with 
the inclusion of biocorrectors of digestion processes. Scientific Works "Food science, engineering and technologies", 1, 334-338. (in Russian)

6. Cherno N.K., Krussir G.V., Yashkyna V.V. 2009 b. Plant complexes that inhibit the action of pancreatic lipase, and their use. Cereal products and feed, 34 (2), 13-17. (in Russian)

7. Council Directive $75 / 442 /$ EEC of 15 July 1975 on waste. (25.07.1975). Official Journal, L 194, 39-41. Available: http://eur-lex.europa.eu/eli/ dir/1975/442/oj

8. Yu.V. Samoilova, K.N. Sorokina, M.A. Nuriddinov, A.S. Rozanov. 2013. Development of a biocatalyst for the transesterification of edible fats using immobilized lipase enzymes. High technology in modern science and technology, 119-123. (in Russian)

9. Directive 2008/98/EC of the European Parliament and of the Council of 19 November 2008 on waste and repealing certain Directives. (22.11.2008). Official Journal, L 312, 3-30. Available: http://eur-lex. europa.eu/eli/dir/2008/98/oj

10. Kovaleva T.A. et al. 2008. Immobilization of hydrolytic enzymes on anion exchangers Sorption and chromatographic processes,. 8(6), 1035-1041. (in Russian)

11. Kates M. 1975. The technique of lipidology. Isolation, analysis and identification of lipids, Mir, Moscow (in Russian)

12. Krussir G.V et al. 2014. Technologies of food waste management: textbook. tool. for universities. Astroprint, Odessa (in Ukrainian)

13. Krussir G.V. 2010. Forecasting of effective methods of stabilization of plant biocorrector., Cereal products and feed, 38( 2), 15-18. (in Ukrainian)

14. Zagorodniy Ya.O. et al. 2012. Methods of utilization of bleaching clays. Energy: Economics, Technologies, Ecology, 1, 97-102. (in Ukrainian)

15. Nekrasov P.O., Plakhotna Yu.M., Nekrasov O.P. 2011. Investigation of the effectiveness of enzymes with respect to hydrolytic fission of fats. Bulletin of the National Technical University KPI, 31, 3-10. (in Ukrainian)

16. O'Brien R. 2007. Fats and Oils. Production, composition, properties, application. Profession, $\mathrm{SPb}$. (in Russian)
17. Paiva A.L., Balcão V.M., Malcata F.X. 2000. Kinetics and mechanisms of reactions catalyzed by immobilized lipases, Enz. Microb. Technol. 1; 27(3-5), 187-204. doi: https://doi.org/10.1016/ S0141-0229(00)00206-4

18. Pieskova L.O., Dekhtiarenko N.V. 2014. Enzyme lipase: analysis of uses, producers, production methods. Scientific reports of the National Technical University of Ukraine KPI, 3, 63-72. (in Ukrainian)

19. Polygalina G.V. 2003. Determination of enzyme activity. Directory. DeLi print, Moscow (in Russian)

20. Ramos E.Z., Miotti Jr R.H., de Castro, P.F., Tardioli, P.W., Mendes A.A., Fernandéz-Lafuente R., Hirata D.B. 2015. Production and immobilization of Geotrichum candidum lipase via physical adsorption on eco-friendly support: Characterization of the catalytic properties in hydrolysis and esterification reactions, J. Mol. Catal. B: Enz. 118, 43. doi: https:// doi.org/10.1016/j.molcatb.2015.05.009

21. Register of waste generation, treatment and disposal facilities. The official website of Vinnitsa Regional State Administration. URL: http:/www.vin.gov.ua/ dep-apr/administratyvni-posluhy/629-diiuchi-dozvoly-reiestry/20545-reestr-ouv-2018(in Ukrainian)

22. Sklyar V., Krussir G., Lebedenko T., Khomich G., Kovalenko I. 2019. Research Study of the Conditions of Wastes Lipolysis Lipid Fraction. Journal of Ecological Engineering, 20, 3, 152-156. DOI: $10.12911 / 22998993 / 99745$

23. Romanovskaya T.I., Romanovsky I.Ya. 2009. The regeneration of refractory clay in oil production. Scientific works ONAFT, 2, 36, 55-57. (in Ukrainian)

24. Skliar V., Krusir G., Zakharchuk V., Kovalenko I., Shpyrko T. 2019. Investigation of the fat fraction enzymatic hydrolysis of the waste from production of hydrogenated fat by the lipase Rhizopus japonicus. Food science and technology, 13,1, 27-33. DOI: http://dx.doi.org/10.15673/fst.v13i1.1332

25. Site Association «Ukroliaprom» Retrieved from http://www.ukroilprom. org.ua/?q=node/205 (in Ukrainian)

26. Gunasekaran V. and Das D., 2005. Lipase fermentation: Progress and prospects, Indian J. Biotechnol, 4, 437-445. 